\title{
HUBUNGAN TINGKAT KEPATUHAN MENGIKUTI PROGRAM PROLANIS TERHADAP PENURUNAN KADAR GULA DARAH PADA PASIEN DIABETES MELLITUS DI UPT PUSKESMASBIHA KABUPATEN PESISIR BARAT
}

\author{
Andoko ${ }^{1}$, Usastiawaty Cik Ayu Saadiah Isnainy ${ }^{2}$, Muhammad Yanuar Irianto $^{3}$ \\ ${ }^{1}$ Dosen PSIK Universitas Malahayati Bandar Lampung \\ Email : andoko2013@gmail.com \\ ${ }^{2}$ Dosen Keperawatan Universitas Malahayati Bandar Lampung \\ Email : usastiawatycasi@gmail.com \\ ${ }^{3}$ Perawat UPT Puskesmas Biha Kabupaten Pesisir barat. \\ Email : muhammadyanuaririanto@gmail.com
}

\section{ABSTRACT : THE CORRELATION BETWEEN ADHERENCE OF FOLLOWING PROLANIS AND GLUCOSE LEVEL DECREASE OF DAIBETES MELLITUS PATIENTS AT BIHA HEALTH CENTER OF PESISIR BARAT REGENCY}

Introduction: Diabetes is a disease signed by high blood glucose level that causes the damage of blood vessels, nerves, and other internal structures. The bad blood circulation through large blood vessel may hurt brain, heart and leg vein. The abnormal blood circulation in the small blood vessel may injure eyes, kidney, nerves, and skin, as well as delay wound recovery. On the hypertensive patients, diabetes mellitus may trigger stroke particularly thrombosis stroke. Objective: of this study was the correlation between adherence of following Prolanis (Chronic Disease Management Program)and glucose level decrease of diabetes mellitus patients at Biha Health Center of Pesisir Barat Regency.

Method: This study was quantitative. The research design used cross sectional approach. The population of the study consisted of 46 registered diabetes mellitus patients at Biha Health Center of Pesisir Barat Regency since January to March 2019. The sampling technique was total population. The data analysis was through chi square.

Result: It is known that there were 25 respondents (54.3\%) were not discipline to follow Prolanis Program at Biha Health Center of Pesisir Barat Regency. There were 31 respondents (67.4\%) had abnormal blood glucose level. Conclusion: Based on the statistical analysis, the $p$ value was 0.021 or the $p$ value $<0.05$ which indicated the correlation between adherence of following Prolanis and glucose level decrease of diabetes mellitus patients at Biha Health Center of Pesisir Barat Regency in 2019. The health practitioners are suggested to actively give counseling to the patients about the importance of managing chronic disease at Prolanis.

Keywords : adherence, prolanis, blood glucose

\footnotetext{
Andoko ${ }^{1}$, Usastiawaty Cik Ayu Saadiah Isnainy ${ }^{2}$, Muhammad Yanuar Irianto ${ }^{3}$ ${ }^{1}$ Dosen PSIK Universitas Malahayati Bandar Lampung. Email : andoko2013@gmail.com

${ }^{2}$ Dosen Keperawatan Universitas Malahayati Bandar Lampung. Email : usastiawatycasi@gmail.com

${ }^{3}$ Perawat Puskesmas Biha Kabupaten Pesisir barat. Email : muhammadyanuaririanto@gmail.com
} 


\section{INTISARI : HUBUNGAN TINGKAT KEPATUHAN MENGIKUTI PROGRAM PROLANIS TERHADAP PENURUNAN KADAR GULA DARAH PADA PASIEN DIABETES MELLITUS DI UPT PUSKESMAS BIHA KABUPATEN PESISIR BARAT}

Pendahuluan: Diabates merupakan kadar gula darah yang tinggi sehingga menyebabkan rusaknya pembuluh darah, saraf, dan struktur interna lainya. Sirkulasi darah yang buruk melalui pembuluh darah besar bisa melukai otak, jantung, dan pembuluh darah kaki, sedangkan pembuluh darah kecil bisa melukai mata, ginjal, saraf, dan kulit, serta memperlambat penyembuhan luka, sedangkan penyakit hipertensi pada diabetes melitus jika tidak ditangani dengan baik maka sangat berpotensi menyebabkan sakit lainnya salah satu yang paling banyak terjadi adalah penyakit stroke, khususnya tipe penyakit stroke thrombolik.

Tujuan: Diketahui hubungan tingkat kepatuhan mengikuti program prolanis terhadap penurunan kadar gula dalam darah pada pasien diabetes melitus Di UPT Puskesmas Biha Kabupaten Pesisir Barat Tahun 2019.

Metode: Jenis penelitian kuantitatif. Rancangan penelitian menggunakan pendekatan cross sectional. Populasi dalam penelitian ini adalah seluruh pasien Diabetes Melitus yang ada Di UPT Puskesmas BIHA Kabupaten Pesisir Barat Tahun 2019 yang terhitung sejak Januari - Maret yang berjumlah 46 orang, Sehingga sampel minimum yang didapatkan berjumlah 46 responden. Dalam penelitian ini teknik sampling yang digunakan adalah total populasi. Analisa data yang digunakan menggunakan uji chi-square.

Hasil : Diketahui bahwa Di UPT Puskesmas Biha Kabupaten Pesisir Barat Tahun 2019, sebagian besar responden tidak patuh berjumlah 25 responden (54,3\%), sebagian besar responden mempunyai kadar gula darah yang tidak normal berjumlah 31 responden $(67,4 \%)$.

Kesimpulan: Berdasarkan hasil uji statistik, diketahui p-value 0,021 atau pvalue $<0,05$ yang artiya terdapat hubungan antara Tingkat Kepatuhan Mengikuti Program Prolanis Terhadap Penurunan Kadar Gula Dalam Darah Pada Pasien Diabetes Melitus Di UPT Puskesmas Biha Kabupaten Pesisir Barat Tahun 2019. Diharapkan selalu aktif dalam memberikan penyuluhan kesehatan khususnya tentang pentingnya pengetahuan tentang peyakit yang dialami pasien dalam program prolanis.

Kata Kunci : kepatuhan, prolanis, kadar gula

\section{PENDAHULUAN}

Diabates merupakan kadar gula darah yang tinggi sehingga menyebabkan rusaknya pembuluh darah, saraf, dan struktur interna lainya. Sirkulasi darah yang buruk melalui pembuluh darah besar bisa melukai otak, jantung, dan pembuluh darah kaki, sedangkan pembuluh darah kecil bisa melukai mata, ginjal, saraf, dan kulit, serta memperlambat penyembuhan luka, sedangkan penyakit hipertensi pada diabetes melitus jika tidak ditangani dengan baik maka sangat berpotensi menyebabkan sakit lainnya salah satu yang paling banyak terjadi adalah penyakit stroke, khususnya tipe penyakit stroke thrombolik (Saputra, 2016).

Diabetes melitus merupakan salah satu penyakit tidak menular

Andoko $^{1}$, Usastiawaty Cik Ayu Saadiah Isnainy ${ }^{2}$, Muhammad Yanuar Irianto ${ }^{3}$

${ }^{1}$ Dosen PSIK Universitas Malahayati Bandar Lampung. Email : andoko2013@gmail.com

${ }^{2}$ Dosen Keperawatan Universitas Malahayati Bandar Lampung. Email : usastiawatycasi@gmail.com

${ }^{3}$ Perawat Puskesmas Biha Kabupaten Pesisir barat. Email : muhammadyanuaririanto@gmail.com 
(PTM) dan jumlah pasien diabetes melitus didunia mencapai 246 juta orang (WHO 2016). Indonesia menempati urutan ke-4 dengan jumlah pasien diabetes melitus terbesar didunia setelah India, Cina dan Amerika Serikat, dengan prevalensi $8,6 \%$ dari total penduduk (WHO, 2016). Secara global, WHO mengatakan bahwa pada tahun 2015 terdapat 1,1 juta penduduk mengalami kematian akibat diabetes melitus dengan prevalensi 1,9\% dan pada tahun 2016 dilaporkan bahwa terdapat 246 juta pasien diabetes melitus, 6 juta kasus baru diabetes melitus dan 3,5 juta penduduk mengalami kematian akibat diabetes melitus. Dari seluruh kematian akibat diabetes melitus di dunia, $70 \%$ kematian terjadi di negara-negara berkembang. Di Indonesia sendiri berdasarkan Profil Kementrian Kesehatan RI Tahun 2016 angka kejadian diabetes mellitus mencapai 4.300 jiwa dan tahun 2017 kini mencapai 4.730 jiwa, dan rata-raa $60 \%$ penderita diabetes mellitus meninggal dunia (Profil Kemenkes RI, 2017).

Berdasarkan data dari Dinas Kesehatan Provinsi Lampung Tahun (2016), prevalensi kasus diabetes melitus pada tahun 2012 sebesar 20,5\%, kemudian pada tahun 2013 sebesar 19,7\%, pada tahun 2014 sebesar 20,7\%, pada tahun 2015 sebesar 20,6\% dan pada tahun 2016 prevalensi penderita diabetes melitus di Provinsi Lampung mencapai 21,3\% menduduki peringkat kedua dalam kasus penyakit tidak menular. Berdasarkan data Dinas Kesehatan Provinsi Lampung, Kabupaten Pesisir Barat sendiri berada pada urutan keenam tertinggi sebesar 30,17\% untuk penyakit DM (Dinas Kesehatan Provinsi Lampung, 2016).

UPT Puskesmas Biha

Kabupaten Pesisir Barat merupakan salah satu Puskesmas dengan kasus penyakit diabetes melitus cukup tinggi, pada taun 2016 angka kejadian diabetes melitus mencapai 45 orang, tahun 2017 mencapai 52 orang dan pada tahun 2018 angka kejadian diabetes melitus mengalami peningkatan hingga mencapai 62 orang. Angka kejadian diabetes melitus semakin tahun mengalami peningkatan dkarenakan kurangnya pengetahuan tentang pencegahan diabetes melitus mengenai pola makan, gaya hidup, faktor diet serta kurangnya kepatuhan pasien dalam menjalani terapi pencegahan diabetes melitus (Profil Puskesmas BIHA Pesisir Barat, 2018).

Saat ini Indonesia mengalami transisi epidemiologi, dimana terjadi penurunan prevalensi penyakit menular namun terjadi peningkatan prevalensi penyakit tidak menular (PTM) atau penyakit degeneratif. Menurut hasil Riset Kesehatan Dasar (Riskesdas) tahun 2018, program pemerintah dalam sistem pelayanan kesehatan dan pendekatan proaktif yang dilaksanakan secara terintegrasi yang melibatkan Peserta, Fasilitas Kesehatan dan BPJS Kesehatan adalah PROLANIS (Program Pengelolaan Penyakit Kronis). Di Indonesia pelaksanaan program Prolanis DM dilakukan oleh apoteker terlatih yang bertugas meresepkan dan menyesuaikan obat bagi pasien DM. Apoteker juga merujuk pasien untuk pemeriksaan laboratorium, memberikan pendidikan dan memastikan kadar glikemik dan tekanan darah.

Andoko ${ }^{1}$, Usastiawaty Cik Ayu Saadiah Isnainy ${ }^{2}$, Muhammad Yanuar Irianto ${ }^{3}$

${ }^{1}$ Dosen PSIK Universitas Malahayati Bandar Lampung. Email : andoko2013@gmail.com

${ }^{2}$ Dosen Keperawatan Universitas Malahayati Bandar Lampung. Email : usastiawatycasi@gmail.com

${ }^{3}$ Perawat Puskesmas Biha Kabupaten Pesisir barat. Email : muhammadyanuaririanto@gmail.com 
Tujuan Prolanis adalah mendorong peserta penyandang penyakit kronis mencapai kualitas hidup optimal pada pemeriksaan spesifik terhadap penyakit DM Tipe 2 sesuai Panduan Klinis terkait sehingga dapat mencegah timbulnya komplikasi. Pengetahuan masyarakat tentang Prolanis perlu ditingkatkan untuk meningkatkan minat dan motivasi karena Prolanis terhenti sejak sekitar tiga bulan yang lalu (terakhir dilaksanakan pertengahan oktober) karena anggaran BPJS tidak turun (Hafizhah, 2017).

Kendala Prolanis merupakan program baru dari pemerintah sehingga banyak masyarakat belum mengetahui, bahkan sebagian besar ada masyarakat yang sudah mengetahui namun kurang patuh dalam mengikuti program Prolanis dan sebagai petugas kesehatan mempunyai kewajiban dalam sosialisasi dan penggerak dalam kegiatan. Pada Prolanis terdapat kerancuan dalam program yang sebagian besar pasien lansia, bukan hanya untuk penyakit kronis, namun di program tersebut pasien penyakit kronis juga otomatis terjaring karena ada pemeriksaan gula darah. Pada Agenda prolanis terdiri atas: senam pagi, pemeriksaan, pengobatan, penyuluhan, dan makan bersama. Pada masalah dana ada pemotongan anggaran dan dananya tidak turun. Padahal dana tersebut sangat diperlukan untuk penyediaan transport petugas, konsumsi peserta, dipstick/alat pemeriksaan lainnya. Pada bagian prolanis lain seperti home visit dan sms gateway tidak dilakukan karena masalah dana (Hafizhah, 2015).

$$
\text { Mensukseskan program }
$$

pemerintah diperlukan sosialisasi dan motivasi tenaga kesehatan tentang prolanis kepada masyarakat dan sehingga akan mengajak pasien DM dan hipertensi berpartisipasi dalam kesuksesan program prolanis adalah suatu sistem pelayanan kesehatan dan pendekatan proaktif yang dilaksanakan secara terintegrasi yang melibatkan peserta, fasilitas kesehatan dan BPJS Kesehatan dalam rangka pemeliharaan kesehatan bagi peserta BPJS Kesehatan yang menderita penyakit kronis untuk mencapai kualitas hidup yang optimal dengan biaya pelayanan kesehatan yang efektif dan efisien, namun kenyataan yang ada di lapangan adalah kurangnya minat serta kepatuhan masyarakat dalam mengikuti program prolanis, hal ini disebabkan karena banyak faktor yaitu kurangnya informasi, kesibukan dan aktifitas, usia, rendahnya pendidikan serta kurangnya dukungan yang diberikan oleh anggota keluarga (BPJS Kesehatan, 2016).

Berdasarkan data prasurvey yang dilakukan Di UPT Puskesmas Biha Kabupaten Pesisir Barat, diketahui terdapat 20 pasien diabetes melitus, setelah dilakukan wawancara didapatkan data bahwa 12 pasien $(60 \%)$ mengatakan tidak patuh dalam mengikuti program Prolanis, hal ini dikarenakan kurangnya pengetahuan pasien tentang pentingnya Prolanis, dan 8 pasien $(40 \%)$ mengatakan pernah mengikuti program Prolanis, namun kini sudah kurang aktif lagi dalam mengikuti program Prolanis.

Andoko ${ }^{1}$, Usastiawaty Cik Ayu Saadiah Isnainy ${ }^{2}$, Muhammad Yanuar Irianto ${ }^{3}$

${ }^{1}$ Dosen PSIK Universitas Malahayati Bandar Lampung. Email : andoko2013@gmail.com

${ }^{2}$ Dosen Keperawatan Universitas Malahayati Bandar Lampung. Email : usastiawatycasi@gmail.com

${ }^{3}$ Perawat Puskesmas Biha Kabupaten Pesisir barat. Email : muhammadyanuaririanto@gmail.com 


\section{Metode Penelitian}

Jenis penelitian ini merupakan penelitian kuantitatif dengan menggunakan rancangan crosssectional. Tempat penelitian dilakukan Di UPT Puskesmas BIHA Kabupaten Pesisir Barat. Waktu penelitian dilakukan pada tanggal 16 - 24 Juli 2019. Populasi dalam penelitian ini adalah seluruh pasien
Diabetes Melitus yang ada Di UPT Puskesmas BIHA Kabupaten Pesisir Barat Tahun 2019 yang terhitung sejak Januari - Maret yang berjumlah 46 orang dengan sampel 46 orang. Dalam penelitian ini teknik sampling yang digunakan adalah total populasi dengan pengolahan data menggunakan aplikasi SPSS versi 20.

\section{Hasil Penelitian}

Karakteristik Responden

Tabel 1 Distribusi Frekuensi Karateristik Responden Usia Di UPT Puskesmas Biha Kabupaten Pesisir Barat

\begin{tabular}{lll}
\hline Usia & Frekuensi & $\begin{array}{l}\text { Persentase } \\
(\%)\end{array}$ \\
\hline $25-30$ & 21 & 45.7 \\
$31-43$ & 25 & 54.3 \\
Jumlah & $\mathbf{4 6}$ & $\mathbf{1 0 0 . 0}$ \\
\hline
\end{tabular}

Berdasarkan tabel 1 diketahui bahwa Di UPT Puskesmas Biha Kabupaten Pesisir Barat Tahun

2019, sebagian besar responden berusia 31 - 43 sebanyak 25 responden $(54,3 \%)$.

Tabel 2 Distribusi Frekuensi Karateristik Responden Pendidikan Di UPT Puskesmas Biha Kabupaten Pesisir Barat

\begin{tabular}{ccc}
\hline Pendidikan & Frekuensi & Persentase (\%) \\
\hline SD & 11 & 23,9 \\
SMP & 14 & 30,4 \\
SMA & 13 & 28,3 \\
D3 & 7 & 15,2 \\
S1 & 1 & 2,2
\end{tabular}

Berdasarkan

Jumlah

46

100.0

pendidikan

tabel 2 diketahui bahwa Di UPT Puskesmas Biha Kabupaten Pesisir responden adalah SMP sebanyak 14 Barat Tahun 2019, sebagian besar responden $(30,4 \%)$.

Tabel 3 Distribusi Frekuensi Karateristik Responden Pekerjaan Di UPT Puskesmas Biha Kabupaten Pesisir Barat

\begin{tabular}{lll}
\hline Pekerjaan & Frekuensi & Persentase (\%) \\
\hline Buruh & 21 & 45,7 \\
PNS & 2 & 4,3 \\
Swasta & 4 & 8,7 \\
Wiraswasta & 19 & 41,3 \\
Jumlah & 46 & 100.0 \\
\hline
\end{tabular}

Andoko ${ }^{1}$, Usastiawaty Cik Ayu Saadiah Isnainy ${ }^{2}$, Muhammad Yanuar Irianto ${ }^{3}$ ${ }^{1}$ Dosen PSIK Universitas Malahayati Bandar Lampung. Email : andoko2013@gmail.com

${ }^{2}$ Dosen Keperawatan Universitas Malahayati Bandar Lampung. Email : usastiawatycasi@gmail.com ${ }^{3}$ Perawat Puskesmas Biha Kabupaten Pesisir barat. Email : muhammadyanuaririanto@gmail.com 
Berdasarkan tabel 3, diketahui bahwa Di UPT Puskesmas Biha Kabupaten Pesisir Barat Tahun
2019, sebagian besar pekerjaan responden adalah sebagai buruh sebanyak 21 responden $(45,7 \%)$.

\section{Analisis Univariat}

Tabel 4.Distribusi Frekuensi Kepatuhan Responden Di UPT Puskesmas Biha Kabupaten Pesisir Barat

\begin{tabular}{ccc}
\hline Kepatuhan & Frekuensi & Persentase (\%) \\
\hline Patuh & 21 & 45.7 \\
Tidak & 25 & 54.3 \\
Patuh & & \\
Jumlah & 46 & 100.0 \\
\hline
\end{tabular}

Berdasarkan tabel 4, diketahui bahwa Di UPT Puskesmas Biha Kabupaten Pesisir Barat Tahun
2019, sebagian besar responden tidak patuh berjumlah 25 responden $(54,3 \%)$.

Tabel 5.Distribusi Frekuensi Kadar Gula Dalam Darah Pada Pasien DM Di UPT Puskesmas Biha Kabupaten Pesisir Barat

\begin{tabular}{lll}
\hline $\begin{array}{l}\text { Kadar } \\
\text { Dalam } \begin{array}{r}\text { Gula } \\
\text { Darah }\end{array}\end{array}$ & Frekuensi & $\begin{array}{l}\text { Persentase } \\
\text { (\%) }\end{array}$ \\
\hline Pada Pasien DM & & \\
\hline Normal & 15 & 32.6 \\
Tidak Normal & 31 & 67.4 \\
Jumlah & 46 & 100.0 \\
\hline
\end{tabular}

Berdasarkan tabel 5, diketahui bahwa Di UPT Puskesmas Biha Kabupaten Pesisir Barat Tahun 2019, sebagian besar responden

\section{Analisa Bivariat}

Untuk Mengetahui Hubungan

Tingkat Kepatuhan Mengikuti

Program Prolanis Terhadap

Penurunan Kadar Gula Dalam Darah mempunyai kadar gula darah yang tidak normal berjumlah 31 responden $(67,4 \%)$.

Pada Pasien Diabetes Melitus Di UPT Puskesmas Biha Kabupaten Pesisir Barat Tahun 2019, maka digunakan analisa bivariat, yaitu:

Tabel 6. Analisis Hubungan Tingkat Kepatuhan Mengikuti Program Prolanis Terhadap Penurunan Kadar Gula Dalam Darah Pada Pasien Diabetes Melitus

\begin{tabular}{|c|c|c|c|c|c|c|c|c|}
\hline \multirow[t]{3}{*}{ Kepatuhan } & \multirow{2}{*}{\multicolumn{2}{|c|}{$\begin{array}{l}\text { Kadar Gula } \\
\text { Pasien DM } \\
\text { Normal }\end{array}$}} & \multicolumn{2}{|c|}{ Dalam } & \multicolumn{2}{|c|}{ Total } & \multirow[t]{3}{*}{$\begin{array}{l}\text { P- } \\
\text { Value }\end{array}$} & \multirow[t]{3}{*}{$\begin{array}{ll}\text { OR } & (\mathrm{Cl} \\
95 \%) & \end{array}$} \\
\hline & & & \multicolumn{2}{|c|}{ Tidak Normal } & & & & \\
\hline & $\mathbf{N}$ & $\%$ & $\mathbf{N}$ & $\%$ & $\mathbf{N}$ & $\%$ & & \\
\hline Patuh & 11 & 52,4 & 10 & 47,6 & 21 & 100,0 & 0,021 & 5,775 \\
\hline Tidak Patuh & 4 & 16,0 & 21 & 84,0 & 25 & 100,0 & & $(1,468-$ \\
\hline Jumlah & 15 & 32,6 & 31 & 67,4 & 46 & 100,0 & & $22,725)$ \\
\hline
\end{tabular}

Andoko ${ }^{1}$, Usastiawaty Cik Ayu Saadiah Isnainy ${ }^{2}$, Muhammad Yanuar Irianto ${ }^{3}$ ${ }^{1}$ Dosen PSIK Universitas Malahayati Bandar Lampung. Email : andoko2013@gmail.com ${ }^{2}$ Dosen Keperawatan Universitas Malahayati Bandar Lampung. Email : usastiawatycasi@gmail.com ${ }^{3}$ Perawat Puskesmas Biha Kabupaten Pesisir barat. Email : muhammadyanuaririanto@gmail.com 
Berdasarkan tabel 6, diketahui bahwa Di UPT Puskesmas Biha Kabupaten Pesisir Barat Tahun 2019, terdapat 21 responden yang patuh, dimana 11 responden $(52,4 \%)$ mempunyai kadar gula yang normal, dan 10 responden $(47,6 \%)$ mempunyai kadar gula yang tidak normal, sedangkan terdapat 25 responden yang tidak patuh, dimana 4 responden $(16,0 \%)$ mempunyai kadar gula darah normal dan 21 responden $(84,0 \%)$ mempunyai kadar gula yang tidak normal.

\section{Pembahasan}

\section{Pembahasan Univariat}

\section{a. Kepatuhan}

Berdasarkan penelitian, menurut peneliti sebagian besar responden tidak patuh mengikuti program prolanis, hal ini dikarenakan faktor pendidikan yang rendah sebab semakin rendah pendidikan sesorang akan mempengaruhi rendah nya tingkat kepatuhan nya, Sebaliknya jika pendidikan seseorang tinggi maka akan meningkatkan kepatuhan.

\section{b. Kadar Gula Dalam Darah}

Berdasarkan penelitian, menurut peneliti sebagian besar kadar gula dalam darah pada responden tidak normal, hal ini dikarenakan terjadi pada responden yang mempunyai keluarga dengan riwayat penyakit Diabetes Mellitus.

\section{Pembahasan Bivariat}

a. Hubungan Tingkat Kepatuhan Mengikuti Program Prolanis Terhadap Penurunan Kadar Gula Dalam Darah Pada Pasien Diabetes Melitus
Berdasarkan hasil uji statistic, diketahui $p$-value 0,021 atau $p$ value $<0,05$ yang artiya terdapat hubungan antara Tingkat Kepatuhan Mengikuti Program Prolanis Terhadap Penurunan Kadar Gula Dalam Darah Pada Pasien Diabetes Melitus Di UPT Puskesmas Biha Kabupaten Pesisir Barat Tahun 2019 dengan nilai OR 5,775 yang artinya responden yang tidak mempunyai kepatuhan berpeluang 5,775 kali lebih besar untuk mengalami kadar gula darah yang tidak normal.

Berdasarkan hasil penelitian, diketahui bahwa Di UPT Puskesmas Biha Kabupaten Pesisir Barat Tahun 2019, terdapat 21 responden yang patuh, dimana 11 responden $(52,4 \%)$ mempunyai kadar gula yang normal, dan 10 responden $(47,6 \%)$ mempunyai kadar gula yang tidak normal, sedangkan terdapat 25 responden yang tidak patuh, dimana 4 responden $(16,0 \%)$ mempunyai kadar gula darah normal dan 21 responden $(84,0 \%)$ mempunyai kadar gula yang tidak normal.

Berdasarkan hasil uji statistic, diketahui $p$-value 0,021 atau pvalue < 0,05 yang artiya terdapat hubungan antara Tingkat Kepatuhan Mengikuti Program Prolanis Terhadap Penurunan Kadar Gula Dalam Darah Pada Pasien Diabetes Melitus Di UPT Puskesmas Biha Kabupaten Pesisir Barat Tahun 2019 dengan nilai OR 5,775 yang artinya responden yang tidak mempunyai kepatuhan berpeluang 5,775 kali lebih besar untuk mengalami kadar gula darah yang tidak normal.

Andoko ${ }^{1}$, Usastiawaty Cik Ayu Saadiah Isnainy ${ }^{2}$, Muhammad Yanuar Irianto ${ }^{3}$ ${ }^{1}$ Dosen PSIK Universitas Malahayati Bandar Lampung. Email : andoko2013@gmail.com

${ }^{2}$ Dosen Keperawatan Universitas Malahayati Bandar Lampung. Email : usastiawatycasi@gmail.com

${ }^{3}$ Perawat Puskesmas Biha Kabupaten Pesisir barat. Email : muhammadyanuaririanto@gmail.com 
Diabates merupakan kadar gula darah yang tinggi sehingga menyebabkan rusaknya pembuluh darah, saraf, dan struktur interna lainya. Sirkulasi darah yang buruk melalui pembuluh darah besar bisa melukai otak, jantung, dan pembuluh darah kaki, sedangkan pembuluh darah kecil bisa melukai mata, ginjal, saraf, dan kulit, serta memperlambat penyembuhan luka, sedangkan penyakit hipertensi pada diabetes melitus jika tidak ditangani dengan baik maka sangat berpotensi menyebabkan sakit lainnya salah satu yang paling banyak terjadi adalah penyakit stroke, khususnya tipe penyakit stroke thrombolik (Saputra, 2016).

Kendala Prolanis merupakan program baru dari pemerintah sehingga banyak masyarakat belum mengetahui, bahkan sebagian besar ada masyarakat yang sudah mengetahui namun kurang patuh dalam mengikuti program Prolanis dan sebagai petugas kesehatan mempunyai kewajiban dalam sosialisasi dan penggerak dalam kegiatan. Pada Prolanis terdapat kerancuan dalam program yang sebagian besar pasien lansia, bukan hanya untuk penyakit kronis, namun di program tersebut pasien penyakit kronis juga otomatis terjaring karena ada pemeriksaan gula darah. Pada Agenda prolanis terdiri atas: senam pagi, pemeriksaan, pengobatan, penyuluhan, dan makan bersama. Pada masalah dana ada pemotongan anggaran dan dananya tidak turun. Padahal dana tersebut sangat diperlukan untuk penyediaan transport petugas, konsumsi peserta, dipstick/alat pemeriksaan lainnya. Pada bagian prolanis lain seperti home visit dan sms gateway tidak dilakukan karena masalah dana (Hafizhah, 2015). Mensukseskan program pemerintah diperlukan sosialisasi dan motivasi tenaga kesehatan tentang prolanis kepada masyarakat dan sehingga akan mengajak pasien DM dan hipertensi berpartisipasi dalam kesuksesan program prolanis adalah suatu sistem pelayanan kesehatan dan pendekatan proaktif yang dilaksanakan secara terintegrasi yang melibatkan peserta, fasilitas kesehatan dan BPJS Kesehatan dalam rangka pemeliharaan kesehatan bagi peserta BPJS Kesehatan yang menderita penyakit kronis untuk mencapai kualitas hidup yang optimal dengan biaya pelayanan kesehatan yang efektif dan efisien, namun kenyataan yang ada di lapangan adalah kurangnya minat serta kepatuhan masyarakat dalam mengikuti program prolanis, hal ini disebabkan karena banyak faktor yaitu kurangnya informasi, kesibukan dan aktifitas, usia, rendahnya pendidikan serta kurangnya dukungan yang diberikan oleh anggota keluarga (BPJS Kesehatan, 2016).

Hasil penelitian ini sejalan dengan penelitian Aditya Primahuda, dkk tentang Hubungan Antara Kepatuhan Mengikuti Program Pengelolaan Penyakit Kronis (PROLANIS) BPJS Dengan Stabilitas Gula Darah Pada Penderita Diabetes Melitus

Andoko ${ }^{1}$, Usastiawaty Cik Ayu Saadiah Isnainy ${ }^{2}$, Muhammad Yanuar Irianto ${ }^{3}$

${ }^{1}$ Dosen PSIK Universitas Malahayati Bandar Lampung. Email : andoko2013@gmail.com

${ }^{2}$ Dosen Keperawatan Universitas Malahayati Bandar Lampung. Email : usastiawatycasi@gmail.com

${ }^{3}$ Perawat Puskesmas Biha Kabupaten Pesisir barat. Email : muhammadyanuaririanto@gmail.com 
Di Puskesmas Babat Kabupaten Laomgan, menyebutkan bahwa Pengambilan data dilakukan menggunakan kuesioner kepatuhan diet, Baecke, MMAS-8 dan rekam medis pasien. Hasil uji statistik menggunakan uji alternatif fisher exact menunjukkan $p=0,000<a(0,05)$ yang berarti terdapat hubungan yang signifikan antara kepatuhan mengikuti PROLANIS dengan stabilitas gula darah. Hal ini menunjukkan bahwa semakin tinggi tingkat kepatuhan maka semakin baik stabilitas gula darahnya. Berdasarkan 4 pilar PROLANIS mayoritas diabetisi tidak patuh terhadap edukasi (61\%), aktivitas fisik (56\%), dan pengobatan $(52,3 \%)$, sedangkan mayoritas diabetisi patuh terhadap diet $(90,2 \%)$.

Berdasarkan hasil penelitian diatas, maka menurut peneliti terdapat sebagian besar responden yang tidak patuh, dan sebagian besar juga responden mempunyai kadar gula darah yang tidak normal, hal ini dikarenakan kurangnya dukungan keluarga kepada responden dalam mengikuti program prolanis, sehingga responden malas untuk menjaga agar kadar gula darahnya tetap normal dan stabil. Dalam hasil penelitian juga peneliti mengetahui bahwasanya ada responden yang patuh namun kadar gula dalam darahnya tidak normal, hal ini dikarenakan faktor pola hidup yang tidak baik, seperti konsumsi makan dan kurangnya aktifitas fisik.

\section{Keterbatasan Penelitian}

1. Pada saat melakukan penelitian, terdapat reponden yang belum mengerti tentang cara pengisian kuesioner sehingga peneliti harus menjelaskan kembali kepada responden secara berulang-ulang.

2. Pada saat penelitian terdapat responden yang terlambat datang sehingga peneliti harus menunggu lama, dan ada yang tidak datang dengan keterangan sibuk bekerja sehingga peneliti harus datang ke rumah responden.

3. Setelah peneliti menjelaskan tujuan dari penelitian, terdapat responden yang kurang mengerti dan ragu untuk menjadi responden, sehingga peneliti harus menjelaskan kembali tujuan penelitian.

\section{Kesimpulan \\ Diketahui bahwa Di UPT Puskesmas Biha Kabupaten Pesisir Barat Tahun 2019, sebagian besar responden berusia 31 - 43 sebanyak 25 responden $(54,3 \%)$, pendidikan responden adalah SMP sebanyak 14 responden $(30,4 \%)$, pekerjaan responden adalah sebagai buruh sebanyak 21 responden $(45,7 \%)$. Diketahui bahwa sebagian besar responden tidak patuh berjumlah 25 responden $(54,3 \%)$. Sebagian besar responden mempunyai kadar gula darah yang tidak normal berjumlah 31 responden $(67,4 \%)$. Berdasarkan hasil uji statistic, diketahui p-value 0,021 atau $p$-value $<0,05$ yang artiya terdapat hubungan antara Tingkat Kepatuhan Mengikuti Program Prolanis Terhadap Penurunan Kadar Gula Dalam Darah Pada Pasien Diabetes Melitus Di UPT Puskesmas Biha Kabupaten Pesisir Barat.}

\footnotetext{
Andoko ${ }^{1}$, Usastiawaty Cik Ayu Saadiah Isnainy ${ }^{2}$, Muhammad Yanuar Irianto ${ }^{3}$ ${ }^{1}$ Dosen PSIK Universitas Malahayati Bandar Lampung. Email : andoko2013@gmail.com ${ }^{2}$ Dosen Keperawatan Universitas Malahayati Bandar Lampung. Email : usastiawatycasi@gmail.com ${ }^{3}$ Perawat Puskesmas Biha Kabupaten Pesisir barat. Email : muhammadyanuaririanto@gmail.com
} 
Saran

Selalu aktif dalam memberikan penyuluhan kesehatan khususnya tentang pentingnya pengetahuan tentang peyakit yang dialami pasien dalam program prolanis. Meningkatkan promosi kesehatan tentang bagaimana perilaku yang baik dalam menghadapi penyakitnya dalam program prolanis. Meningkatkan skill kepada seluruh tenaga keperawatan tentang bagaimana cara memberikan pelayanan terhadap pasien yang mempunyai peyakit melalui pelatihan. Diharapkan untuk peneliti selanjutnya agar dapat melakukan penelitian lebih lanjut tentang faktor-faktor yang berhubungan dengan rendahnya kunjungan pasien program prolanis.

\section{DAFTAR PUSTAKA}

Bastable, Susan. (2012). Perawat Sebagai Pendidik PrinsipPrinsip Pengajaran Dan Pembelajaran. Jakarta: EGC.

Fitriani, Sinta. (2010). Promosi Kesehatan. Yogyakarta: Graha IImu.

Kuntoro, Agus. (2010). Buku Ajar Manajemen Keperawatan. Yogyakarta: Nuha Medika.

Mubarak.(2009). Promosi Kesehatan Dan Prilaku Kesehatan. Jakarta: PT. Rineka Cipta.

Nursalam. (2016). Manajemen Keperawatan Aplikasi Dalam Praktik Keperawatan Profesional. Jakarta: Salemba Medika.

Priyoto. (2015). Komunikasi Dan Sikap Empati Dalam
Keperawatan. Yogyakarta: Graha Ilmu.

Primahuda, dkk tentang Hubungan Antara Kepatuhan Mengikuti Program Pengelolaan Penyakit Kronis (PROLANIS) BPJS Dengan Stabilitas Gula Darah Pada Penderita Diabetes Melitus Di Puskesmas Babat Kabupaten Laomgan

Pradyta, dkk tentang Perilaku Pemanfaatan Prolanis Dengan Status Kesehatan Pasien Diabetes Mellitus Di Kota Purwokerto.

Profil Puskesmas Biha. 2018. Profil Kesehatan. Pesisir Barat. Lampung.

Riskedas. (2015). Program Pengelolaan Penyakit Kronis. Jakarta: Depkes.
Suarli. (2012). Manajemen Keperawatan Dengan Pendekatan Praktis. Jakarta: Penerbit Erlangga.

Soetijiningsih. (2008). Modul Komunikasi Pasien - Dokter. Jakarta: EGC.

Andoko ${ }^{1}$, Usastiawaty Cik Ayu Saadiah Isnainy ${ }^{2}$, Muhammad Yanuar Irianto ${ }^{3}$ ${ }^{1}$ Dosen PSIK Universitas Malahayati Bandar Lampung. Email : andoko2013@gmail.com

${ }^{2}$ Dosen Keperawatan Universitas Malahayati Bandar Lampung. Email : usastiawatycasi@gmail.com

${ }^{3}$ Perawat Puskesmas Biha Kabupaten Pesisir barat. Email : muhammadyanuaririanto@gmail.com 